\title{
PLASMA HOMOCYSTEINE LEVEL AND C677T POLYMORPHISM IN MTHFR GENE IN PATIENTS WITH ACUTE CORONARY SYNDROME
}

\author{
Andrey V. Grek, \\ Lyudmyla N. Prystupa, \\ Tatiana V. Sytnik ${ }^{1}$ \\ Internal Medicine Department of
Postgraduation Education
${ }^{1}$ Student, Medical Institute
Sumy State University Ukraine
}

Corresponding Author:

Andrey V.Grek

Internal Medicine Department of

Postgraduation Education

Medical Institute

Sumy State University

48, Troitskaya str.

Sumy, 40022

Ukraine

e-mail:kubul@mail.ru

Received: February 02, 2015

Revision received: April 04, 2015

\begin{abstract}
Summary
Cardiovascular diseases (CVD) of atherosclerotic origin and accompanying complications are a major cause of mortality in the world and Ukraine, in particular. Endothelial dysfunction is the key cause of atherosclerosis and atherothrombosis. One of the causes of endothelial dysfunction is hyperhomocysteinemia that may occur on the background of MTHFR (methylenetetrahydrofolate reductase) mutation.

Thus, the goal of the study was to investigate the interrelation between homocysteine $(\mathrm{Hc})$ level and MTHFR polymorphism in patients with acute coronary syndrome (ACS).

161 patients with ischemic heart disease and ACS have been examined. The control group comprised 87 healthy individuals. Homocysteine level was the highest in the patients having ACS with ST-segment elevation and complicated course, and was 1.8 times higher than $\mathrm{Hc}$ level in the control group. The patients with the most severe ACS course comprised $27 \%$ of homozygotes for the major allele $\mathrm{C}$ and $41 \%$ of homozygotes for the minor allele T. Comparing the distribution of MTHFR gene C677T polymorphism in patients with ACS that were stratified by plasma $\mathrm{Hc}$ level, we observed a statistically significant association, $\mathrm{P}<0.030$ by chi-square test. We confirmed that these patients had a high $\mathrm{T} / \mathrm{T}$ genotype frequency of MTHFR C677T polymorphism. The obtained data proved the association of $\mathrm{T} / \mathrm{T}$ genotype of MTHFR C677T polymorphism with increased Hc level as well as ACS severity.
\end{abstract}

Key words: MTHFR, acute coronary syndrome, cardiovascular diseases, homocysteine

\section{Introduction}

Cardiovascular diseases (CVD) of atherosclerotic origin and accompanying complications are a major cause of mortality in the world and Ukraine, in particular [1-3]. In low- and middle-income countries more than $80 \%$ of mortality causes are accounted for by CVD. According to estimates provided by WHO, CVD remain a major cause of death; by 2030 the death rate due to CVD will increase to 23.3 million [1, 4]. Since traditional risk factors for CVD do not fully explain the prevalence 
and incidence of these diseases, it is urgent to search for new risk factors of cardiovascular diseases, early detection of which would help to reduce the death rate from this disease.

Among the numerous modern theories of the pathogenesis of atherosclerosis, much attention is paid to the concept, which states atherosclerotic process as the inflammation that occurs in arterial wall due to solution of continuity of arterial endothelium [5]. However, a lot of scientific studies have defined later that the initiator of atherogenesis is endothelial dysfunction (an imbalance among mediators acting oppositely) rather than endothelial lesion [6-9].

There are many factors causing endothelial dysfunction, such as high concentrations of low density lipoproteins and modified low density lipoproteins, increasing of free radicals in blood, Chlamidia pneumonia infection [10-15]. In 1969 the homocysteine theory of atherogenesis was first suggested [16]. Homocysteine is an amino acid that is biosynthesized from methionine and is a homologue of the amino acid cysteine. Methionine is obtained from the diet as a part of protein; it is metabolized to give Sadenosylhomocysteine, which is converted into $\mathrm{Hc}$ in the process of hydrolysis. According to the homocysteine theory, $\mathrm{Hc}$ is one of the main causative factors for endothelial dysfunction [1720].

The association between the increase of plasma $\mathrm{Hc}$ concentration and increased risk of cardiovascular diseases was conclusively established during Framingham Heart Study (1996). European Collaborative Study found out that hyperhomocysteinemia represents an independent modified CVD risk factor. The most reliable evidence of the association between CVD and $\mathrm{Hc}$ has been obtained in prospective cohort design studies: Physicians Health Study, British United Provident Study, Trombo Study, British Regional Heart Study [21-24]. The findings demonstrated that $\mathrm{Hc}$ is an independent risk indicator for the diseases of cardiovascular system, which is even more informative, than cholesterol. Hyperhomocisteinemia (HHc) unfavorably influences the mechanisms involved in vascular tone regulation, lipid metabolism and coagulation cascade $[25,26]$. It has been published that $\mathrm{Hc}$ stimulates platelet aggregation, disrupts the function of tissue plasminogen activator, contributes to binding of lipoproteins to fibrin as well as inhibits the function of such natural anticoagulants as antithrombin III and protein $\mathrm{C}$. In addition, $\mathrm{Hc}$ stimulates some coagulation factors (i.e. V, X и XII) [27, 28].

Blood Hc concentration can rise due to many causes. Mostly, Hc concentration increase occurs due to the lack of vitamins. Low intake of folic acid and B6, B12 and B1 vitamins is especially harmful. The following factors are considered to increase Hc: smoking; alcohol abuse; excessive use of coffee, meat and cholesterol-containing products; diabetes mellitus and renal failure. It is known that HHc can be caused by hereditary diseases, attributable to the deficit of enzymes involved in Hc metabolism [32]. In particular, the increase of plasma Hc concentration occurs in the setting of methylenetetrahydrofolate reductase (MTHFR) mutation, which causes disorders in vitamin B12-dependent remethylation of $\mathrm{Hc}$ to methionine [29].

The most well-known MTHFR gene polymorphism is the one, in which cytosine nucleotide (C) at 677 location in exon 4 is replaced with thymidine $(\mathrm{T})$; this leads to substitution valine amino-acid residue for alanine residue in the location of binding with flavin adenine dinucleotide cofactor. Due to the structural change in this region, enzyme dissociation with cofactor goes too quickly to perform its catalytic function properly and adequately. In 1999 L.B. Bailey and J.F Gregory demonstrated in vitro a $30 \%$ decrease of MTHFR activity in homozygotes for T-allele and $65 \%$ decrease - in heterozygotes as compared with normal level [30]. Moreover, it has been shown that TT-genotype initiates approximately a twofold increase of Hc level as compared with CC-individuals [31].

The goal of the study is to investigate the interrelation between $\mathrm{Hc}$ level and MTHFR polymorphism in patients with acute coronary syndrome (ACS).

\section{Materials and Methods}

The study was approved by the Ethics Committee of Medical Institute of Sumy State University. Prior to the study, each patient gave written informed consent to participate in the study. 161 patients with ischemic heart disease have been examined. The control group comprised 87 healthy individuals. The examined patients were undergoing treatment at Sumy Regional Cardiologic Dispensary of Sumy Regional Council Municipal Institution from January to July of 2012 . 
ACS was diagnosed on the basis of: anamnesis and complaints, clinical examination, blood pressure measurement, over-time 12-lead ECG, laboratory tests (complete blood count and clinical urinalysis, over-time creatine phosphokinase (3 times), creatine phosphokinase-MB, lactate dehydrogenase, lipid profile). All patients were treated according to the Order № 436 of Ministry of Healthcare of Ukraine, dated 03.07.2006. The patients were divided into 4 clinical groups: Group I consisted of 28 patients having ACS with ST-segment elevation and uncomplicated course; group II comprised 24 patients having ACS with STsegment elevation and complicated course; group III consisted of 55 patients having ACS without ST-segment elevation and uncomplicated course; group IV - 54 patients with ACS without STsegment elevation and complicated course.

Hc level study was performed at the clinical diagnostic laboratory of FLORIS Health Center (accreditation certificate № 001415 of 16.11.2009) by means of enzyme immunoassay analyzer «IMMULITE ONE, DPA» (USA), applying «IMMULITE 1000 Homocysteine» and «IMMULITE 1000 vitamin B12» reagents according to the manufacturer's instructions. Hc level evaluation was performed under the classification of DACH.Liga: Hc level $<10$ $\mu \mathrm{mol} / \mathrm{L}$ is a safe level, $10-12 \mu \mathrm{mol} / \mathrm{L}$ is considered a border-line level, $12-30 \mu \mathrm{mol} / \mathrm{L}$ is equal to a moderate $\mathrm{HHc}$ [32].

C677T polymorphism in exon 4 of the MTHFR gene was determined by polymerase chain reaction with restriction fragment length polymorphism assay (PCR-RFLP) at the molecular-genetic research laboratory of Medical Institute of Sumy State University.

Statistical analysis was performed using SPSS-17 program. Thus the significance of differences was estimated by means of chi-square test. P-value $<0.05$ was considered significant.

\section{Results}

According to the results of $\mathrm{Hc}$ content study, $\mathrm{Hc}$ level in patients with ACS was higher than that in the control group. The highest plasma $\mathrm{Hc}$ concentration was observed in the second group of patients and constituted $16.6 \pm 0.31 \mathrm{mcmol} / \mathrm{L}$, which is 1.3 times higher than the indicators in the first group; 1.7 times higher than in the third group; 1.3 times higher than in the fourth group and 1.8 times higher than in the control group (Table 1).

Comparing the distribution of MTHFR gene C677T polymorphism in patients with ACS from different clinical groups, we observed a statistically significant association, $\mathrm{P}<0.001$, by chi-square test (Table 2). The group II patients with the most severe ACS course comprised $27 \%$ of homozygotes for the major allele C, $32 \%$ of heterozygotes and $41 \%$ of homozygotes for the minor allele $\mathrm{T}$. The patients of group I constituted $47.6 \%, 33.3 \%$ and $19.1 \%$; the patients of group III constituted $52.7 \%, 43.6 \%$ and $3.7 \%$; the fourth group constituted $65.4 \%, 28.8 \%$ and $5.8 \%$ for $\mathrm{C} / \mathrm{C}, \mathrm{C} / \mathrm{T}$ and $\mathrm{T} / \mathrm{T}$, respectively. On the other hand, $50 \%$ of ACS patients with the minor allele $\mathrm{T}$ had ACS with ST-segment elevation and complicated course.

Comparing the distribution of MTHFR gene C677T polymorphism in patients with ACS depending on the concentration of $\mathrm{Hc}$ in plasma blood, we observed the absence of a statistically significant association, $\mathrm{P}>0.05$, by chi-square test. Among the patients with moderate $\mathrm{HHc}$, the distribution of $\mathrm{C} / \mathrm{C}, \mathrm{C} / \mathrm{T}$ and $\mathrm{T} / \mathrm{T}$ genotypes were: $53.3 \%, 25 \%, 21.7 \%$. Patients with safe and boundary levels of $\mathrm{Hc}$, carrying distribution of genotypes for the following polymorphism: $55.6 \%, 33.3 \%$ and $11.1 \%$ and $42.9 \%, 42.9 \%$ and $14.3 \%$ respectively. Among patients homozygous for the minor allele T $76.4 \%$ had a moderate $\mathrm{HHc}$ (Table 3 ).

Table 1. Homocysteine level in patients with acute coronary syndrome

\begin{tabular}{llllll}
\hline & $\begin{array}{l}\text { Control. } \\
\mathrm{mcmol} / \mathrm{L}\end{array}$ & $\begin{array}{l}\text { Group I. } \\
\mathrm{n}=18\end{array}$ & $\begin{array}{l}\text { Group II. } \\
\mathrm{n}=18\end{array}$ & $\begin{array}{l}\text { Group III. } \\
\mathrm{n}=33\end{array}$ & $\begin{array}{l}\text { Group IV. } \\
\mathrm{n}=23\end{array}$ \\
\hline $\begin{array}{l}\text { Homocysteine. } \\
\mathrm{mcmol} / \mathrm{L}\end{array}$ & $9.1 \pm 0.48$ & $12.7 \pm 0.14$ & $16.6 \pm 0.31$ & $9.9 \pm 0.56$ & $13.2 \pm 0.26$ \\
\hline
\end{tabular}


— Grek A., et al. Plasma homocysteine level and c677t polymorphism in MTHFR gene in patients ...

Table 2. Genotype frequency of methylenetetrahydrofolatereductase gene C677T polymorphism in subjects with acute coronary syndrome from different clinical groups

\begin{tabular}{lllll}
\hline \multirow{2}{*}{$\begin{array}{llll}\text { Control } \\
\text { groups }\end{array}$} & Frequency & \multicolumn{3}{c}{ MTHFR genotype } \\
\cline { 3 - 5 } I & $\mathrm{N}$ & $\mathrm{C} / \mathrm{C}$ & $\mathrm{C} / \mathrm{T}$ & $\mathrm{T} / \mathrm{T}$ \\
\hline \multirow{2}{*}{$\mathrm{II}$} & $\%$ & 10 & 7 & 4 \\
& $\mathrm{~N}$ & $12.7 \%$ & $13.2 \%$ & $22.2 \%$ \\
\hline \multirow{2}{*}{ III } & $\%$ & 6 & 7 & 9 \\
& $\mathrm{~N}$ & $7.6 \%$ & $13.2 \%$ & $50.0 \%$ \\
\hline \multirow{2}{*}{$\mathrm{IV}$} & $\%$ & 29 & 24 & 2 \\
& $\mathrm{~N}$ & $36.7 \%$ & $45.3 \%$ & $11.1 \%$ \\
\hline
\end{tabular}

Table 3. Genotype frequency of methylenetetrahydrofolatereductase gene C677T polymorphism in subjects with acute coronary syndrome and different plasma homocysteine levels

\begin{tabular}{lllll}
\hline \multirow{2}{*}{ Homocysteine level groups } & \multirow{2}{*}{ Frequency } & \multicolumn{3}{c}{ MTHFR genotype } \\
\cline { 3 - 5 } & & $\mathrm{C} / \mathrm{C}$ & $\mathrm{C} / \mathrm{T}$ & $\mathrm{T} / \mathrm{T}$ \\
\hline \multirow{2}{*}{ Safe 1 evel } & $\mathrm{n}$ & 10 & 6 & 2 \\
& $\%$ & $20.8 \%$ & $22.2 \%$ & $11.8 \%$ \\
\hline \multirow{2}{*}{ Borderline level } & $\mathrm{n}$ & 6 & 6 & 2 \\
& $\%$ & $12.5 \%$ & $22.2 \%$ & $11.8 \%$ \\
\hline \multirow{2}{*}{ Moderate hyperhomocysteinemia } & $\mathrm{n}$ & 32 & 15 & 13 \\
& $\%$ & $66.7 \%$ & $55.6 \%$ & $76.4 \%$ \\
\hline
\end{tabular}

\section{Discussion}

Hence, the highest Hc level was observed in group II patients with complicated ACS and ST elevation. Hc level in group II patients was significantly higher as compared with that in groups I $(p<0.001)$, III $(p<0.001)$ and IV $(p<0.001)$. We also noted that Hc level was significantly higher in the patients of group I, comparing with group III $(p<0.05)$, but had no significant difference with the concentration $\mathrm{Hz}$ patients IV group ( $>0.05$ ), and significantly lower in the patients of group III, compared to the fourth group $(\mathrm{p}<0.01)$ (Table 1). These data demonstrate a relationship between the level Hs and the severity of clinical course of ACS. This are consonant with the results provided by
Nygard O et al. (1997) and Oudi ME (2010), who demonstrated that Hc level in ACS patients with three-vessel disease was higher than in ACS patients with one- or two-vessel disease; the levels were $23.7 \pm 10.37,16.3 \pm 5.46$ and $13.9 \pm 4.89 \mathrm{mcmol} / \mathrm{L}$, respectively [33, 34]. Studies of foreign authors also demonstrated that the increase in $\mathrm{Hc}$, beginning with $10 \mathrm{mcmol} / \mathrm{L}$, is associated with the increased risk of cardiovascular disease [32, 34, 35]. The results of our study show that ACS patients, compared to the control group, had a significantly higher Hc level, which was associated with the severity of clinical course.

A considerable association was observed between MTHFR gene C677T polymorphism and ACS course severity. This is confirmed by the 
maximum frequency of detected minor allele homozygotes in patients with the most severe course of ACS. These results are congruent with other researches' findings that indicate an interrelation between C677T polymorphism and arterial thrombosis; the risk of the latter was higher in homozygotes for T-allele [36-38]. The data about association of $677 \mathrm{~T}$ allele with ischemic attacks in our study can be explained, in our opinion, by the interrelationship between MTHFR gene C677T polymorphism and plasma $\mathrm{Hc}$ level. So, moderate HHs was found in $65.2 \%$ of patients. The frequency of patients with genotype $\mathrm{T} / \mathrm{T}$ by $\mathrm{S} 677 \mathrm{~T}$ polymorphism of MTHFR gene in 6.5 times were higher than the frequency of patients with genotype $\mathrm{C} / \mathrm{C}$ and $\mathrm{C} / \mathrm{T}$. Established in our trial connection between MTHFR gene C677T polymorphism and increased level Hs comparing with patients $\mathrm{C} / \mathrm{C}$ genotype is consonant with investigation's results of another scientists. Brattström et al. (1998), Martin Y.N. et al. (2006) and Xu H. et al. (2013) proved that T/T-genotype and associated increase of $\mathrm{Hc}$ level are the indicators of instability of atherosclerotic plaques [39-41]. Established connection between T/T-genotype, $\mathrm{Hc}$ level and ACS course severity is confirmation with these results.

\section{Conclusions}

These results indicate that $\mathrm{Hc}$ increase is associated with the development of severe ACS.

The frequency of T/T allele of MTHFR gene C677T polymorphism was the highest in the patients of the second group, who had the most severe ACS, as compared to other groups.

We have confirmed the association of MTHFR gene C677T polymorphism and high homocysteinemia with ACS course severity.

\section{References}

1. World Health Organization [Internet]. Geneva: Global status report on noncommunicable diseases 2010. [updated 2011 Apr; cited 2014 Dec 9]. Available from:

http://www.who.int/nmh/publications/ncd_report 2010/en/.

2. Gorbas IM, Barna OM, Sakalosh VY, Bakumenko MA. [Estimated prevalence and control of risk factors for cardiovascular disease in the population and physicians]. Liky Ukrainy.
3. Gaydaev YO, Kornatchkyi VM. [Health problems and directions of its improvement in modern conditions]. Ukr. Kardiol. J. 2007;(5):7. Ukrainian.

4. Mathers CD, Loncar D. Projections of global mortality and burden of disease from 2002 to 2030 . PLoS Med, 2006,3(11):e 442.

5. Spagnoli LG, Bonnano E., Sangiorgi G, Mauriello A. Role of inflammation in atherosclerosis. J Nucl Med. 200748(11):1800-15.

6. Libby P. Inflammatory mechanisms: the molecular basis of inflammation and disease. Nutr rev. 2007;65(12 Pt 2):140-6.

7. Shan P.K. Molecular mechanisms of plaque instability. Curr Opin Lipidol. 2007;18(5):492-9.

8. Sumagin R, Sarelius I. A role for ICAM-1 in maintenance of leucocite-endothelial cell rolling interactions in inflammed arteries. Am J Physiol Heart Circ Physiol. 2007;293(5):H2786-98.

9. Pereira IA, Borba EF. The role of inflammation, humoral and cell mediated autoimmunity in the pathogenesis of atherosclerosis. Swiss Med Wkly. 2008;138(37-38):534-9.

10. Stancu CS, Toma L, Sima AV. Dual role of lipoproteins in endothelial cell dysfunction in atherosclerosis. Cell Tissue Res. 2012;349(2):43346.

11. Lusis AJ. Atherosclerosis. Nature. 2000;407:23341.

12. Etsuo N. Do free radicals play causal role in atherosclerosis? Low density lipoprotein oxidation and vitamin E revisited. J Clin Biochem Nutr. 2011;48(1):3-7.

13. Griendling KK, Alexander RW. Oxidative stress and cardiovascular disease. Circulation. 1997;96(10): 3264-5.

14. Watson C, Nicholas J. ALP. Role of Chlamydia pneumoniae in atherosclerosis.Clin Sci. 2008;114:509-31.

15. Jackson LA, Campbell LA, Schmidt RA, Kuo CC, Cappuccio AL, Lee MJ, et al. Specificity of detection of Chlamydia pneumoniae in cardiovascular atheroma: evaluation of the innocent bystander hypothesis. Am J Pathol. 1997;150(5):1785-90.

16. McCully KS. Vascular pathology of homocysteinemia: implications for the pathogenesis of atherosclerosis. Am J Pathol. 1969;56(1):111-28.

17. McDowell IF, Lang D. Homocysteine and endothelial dysfunction: a link with cardiovascular disease. J Nutr. 2000;130(2S Suppl):369S-72S.

18. Austin RC, Lentz SR, Werstuck GH. Role of hyperhomocysteinemia in endothelial dysfunction and atherothrombotic disease. Cell Death Differ. 2004;11 Suppl 1:S56-64.

19. AbdulleAM, Pathan JY, Moussa N, Gariballa S. Association between homocysteine and endothelial dysfunction markers in stroke disease. Nutr Neurosci. 2010;13(1):2-6. 
20. Verhoef P, Stampfer MJ. Prospective studies of homocysteine and cardiovascular disease. Nutr Rev. 1995;53910):283-8.

21. Stampfer M, Malinow M. Can lowering homocysteine levels reduce cardiovascular risk? N Engl J Med. 1995;33295):328-9.

22. Graham M, Daly L, Refsum H, Robinson K, Brattström LE, Ueland PM, et al. Plasma homocysteine as a risk factor for vascular disease: the European concerted action project. JAMA. 1997;277(22):1775-81.

23. Mayer E, Jacobsen D, Robinson K. Homocysteine and coronary atherosclerosis. J Am Coll Cardiol. 1996;27(3):517-27.

24. Hankey GJ, Eikelboom JW. Homocysteine and vascular disease. Lancet. 1999;354(9176):407-13.

25. Burtina IY. [Effect of the composite preparation Cardonat on plasma homocysteine level in patients with coronary artery disease]. Ukrain Med. Chasopis. 2005;1(45): 45-8. Russian.

26. Blacher J, Benetos A, Kirzin J, Malmejac A, Guize L, Safar ME. Relation of plasma homocysteine to cerebrovascular mortality in a French population. Am J Cardiol. 2002;90(6):591-5.

27. Ciaccio M, Bivona G, Bellia C. Therapeutical approach to plasma homocysteine and cardiovascular risk reduction. Ther Clin Risk Manag. 2008;4(1):219-24.

28. Trabetti E. Homocysteine, MTHFR gene polymorphisms, and cardio-cerebrovascular risk. J Appl Genet. 2008;49(3):267-82.

29. Bjelland I, Tell GS, Vollset SE, Refsum H, Ueland PM. Folate, vitamin B12, homocysteine, and the MTHFR $677 \mathrm{C}->\mathrm{T}$ polymorphism in anxiety and depression: the Hordaland Homocysteine Study. Arch Gen Psychiatry. 2003;60(6):618-26.

30.Bailey LB, Gregory JF 3rd. Polymorphisms of methylenetetrahydrofolate reductase and other enzymes: metabolic significance, risks and impact on folate requirement. J Nutr. 1999;129(5):919-22.

31. Martin YN, Salavaggione OE, Eckloff BW, Wieben ED, Schaid DJ, Weinshilboum RM. Human methylenetetrahydrofolate reductase pharmacogenomics: gene resequencing and functional genomics. Pharmacogenetics and Genomics. 2006;16(4):265-77.

32. Stanger O, Herrmann W, Pietrzik K, Fowler B, Geisel J, Dierkes J, et al. Consensus paper on the rational clinical use of homocysteine, folic acid and B-vitamins incardiovascular and thrombotic diseases: guidelines and recommendations. Clin Chem Lab Med. 2003;41:1392-403.
33. Nygård O, Nordrehaug JE, Refsum H, Ueland PM, Farstad M, Vollset SE. Plasma homocysteine levels and mortality in patients with coronary artery disease. N Engl J Med. 1997;337(4):230-36.

34.Oudi ME, Aouni Z, Mazigh C, Khochkar R, Gazoueni E, Haouela H, et al. Homocysteine and markers of inflammation in acute coronary syndrome. Exp Clin Cardiol. 2010;15(2):e25-28.

35. Haynes WG. Hyperhomocysteinemia, vascular function and atherosclerosis: effects of vitamins. Cardiovasc Drug Ther. 2002;16(5):391-9.

36. Keijzer MB, den Heijer M, Blom HJ, Bos GM, Willems HP, Gerrits WB, et al. Interaction between hyperhomocysteinemia, mutated methylenetetrahydrofolate-reductase (MTHFR) and inherited thrombophilic factors in venous thromboembolism. Thromb Haemost. 2002;88(5):723-8.

37. Den Heijer M, Lewington S, Clarke R. Homocysteine, MTHFR and risk of venous thrombosis: a meta-analysis of published epidemiological studies. J Thromb Haemost. 2005;3(2):292-9.

38. Frederiksen J, Juul K, Grande P, Jensen GB, Schroeder TV, Tybjaerg-Hansen A, et al. Methylenetetrahydrofolate reductase polymorphism (C677T), hyperhomocysteinemia, and risk of ischemic cardiovascular disease and venous thromboembolism: prospective and casecontrol studies from the Copenhagen City Heart Study. Blood. 2004;104:3046-51.

39. Brattström L, Wilcken DE, Ohrvik J, Brudin L. Common methylenetetrahydrofolate reductase gene mutation leads to hyperhomocysteinemia but not to vascular disease: the result of a metaanalysis. Circulation. 1998;98(23):2520-6.

40. Martin YN, Salavaggione OE, Eckloff BW, Wieben ED, Schaid DJ, Weinshilboum RM. Human methylenetetrahydrofolate reductase pharmacogenomics: gene resequencing and functional genomics. Pharmacogenet Genomics. 2006;16:265-77.

41.Xu H, Liu C, Wang Q. Plaque image characteristics, hyperhomocysteinemia, and gene polymorphism of homocysteine metabolismrelated enzyme (MTHFR C677T) in acute coronary syndrome. Cell Biochem Biophys. 2013;66(2): P. 403-7. 